Revista Brasileira de Farmacognosia Brazilian Journal of Pharmacognosy 21(6): 1144-1149, Nov./Dec. 2011

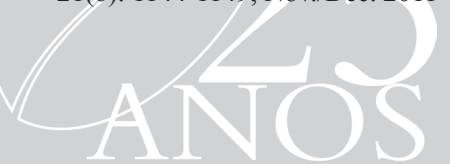

Article

Received 3 Jan 2011

Accepted 16 Feb 2011

Available online 29 Jul 2011

Keywords:

ICP-OES

Melissa officinalis

Mineral composition

Nepeta cataria

Passiflora caerulea

Tilia $x$ moltkei

Valeriana officinalis

ISSN 0102-695X

http://dx.doi.org/10.1590/S0102-

695X2011005000129

\section{Evaluation of macro and microminerals in crude drugs and infusions of five herbs widely used as sedatives}

\author{
Marta E. Petenatti, ${ }^{1}$ Elisa M. Petenatti, ${ }^{1}$ Luis A. Del Vitto, ${ }^{1}$ \\ Mauricio R. Téves, ${ }^{1}$ Néstor O. Caffini, ${ }^{2}$ Eduardo J. Marchevsky, ${ }^{3}$ \\ Roberto G. Pellerano ${ }^{* 3}$
}

\author{
${ }^{1}$ Herbarium/Project 22Q-016, Universidad Nacional de San Luis, Argentina, \\ ${ }^{2}$ Laboratorio de Investigacion de Proteinas Vegetales, Universidad Nacional de La \\ Plata, Argentina, \\ ${ }^{3} I N Q U I S A L$, Departmento de Química Analítica, Universidad Nacional de San Luis \\ CONICET, Argentina.
}

\begin{abstract}
It has been determined the concentration of fourteen micro and macrominerals ( $\mathrm{Al}, \mathrm{Ca}, \mathrm{Co}, \mathrm{Cr}, \mathrm{Cu}, \mathrm{Fe}, \mathrm{K}, \mathrm{Li}, \mathrm{Mg}, \mathrm{Mn}, \mathrm{Na}, \mathrm{P}, \mathrm{Se}$, and $\mathrm{Zn}$ ) in both crude drugs and infusions of Melissa officinalis L., Lamiaceae, Nepeta cataria L., Lamiaceae, Passiflora caerulea L., Passifloraceae, Tilia $x$ moltkei Späth ex C.K. Schneid., Tiliaceae, and Valeriana officinalis L., Caprifoliaceae. These herbs are widely consumed by its sedative properties, either alone or in herb mixtures. All measurements were performed using an inductively coupled plasma optical emission spectrometer (ICP-OES). The products were obtained from regional markets, mainly in San Luis province (Argentina). The estimated daily intake was compared with current recommendations. All products and its infusions were included within the upper tolerable limits for minerals, in trace elements such as toxic elements present at low levels.
\end{abstract}

\section{Introduction}

In recent years the nervous (mainly stress and anxiety) and sleep disorders increased considerably, becoming prevalent diseases affecting a high percentage of the population (Pollak et al., 2009). Often these conditions are treated with longterm use of benzodiazepine analogues, although these drugs show limited benefits with obvious sideeffects, such as impaired cognitive function, memory and general daytime performance. In addition, longterm administration can results in tolerance and dependence.

Herbal drugs have been gradually accepted as remedies all around the world because of their safety and efficacy (Roth \& Drake, 2004), and many herbal sedative products widely available can perform the same therapeutic action with fewer side effects, dependence or tolerance than synthetic pharmaceuticals (Cass, 2004). Some herbal remedies have become increasingly popular treatments for stress, anxiety, dementia, and forgetfulness (Carlini, 2003; Kinrys et al., 2009), used mostly in the form of herbal infusion.

Although many of these herbs or supplements appear to be safe, World Health Organization (WHO) has stressed the need to set up quality standards for medicinal drugs of plant origin, given the marked increase in consumption that has taken place in recent decades (Yeh et al., 2002), the large number of species involved, and the potential side effects or interact both with standard pharmaceuticals and other supplements (Carrasco et al., 2009; Ernst, 2002; Murphy et al., 2005; WHO, 2004). The consumers are not informed about the possible toxicity of these products, and toxicity itself depends on the level of product contamination, as well as on the route of administration, quantity, frequency and duration of intake. Considering the complexity of these drugs and their inherent biological variation, it is necessary to evaluate their quality, safety and efficacy (WHO, 2007). Of course, this is applicable to natural medicines used in treating central nervous system disorders (Coleta et al., 2001; Kinrys et al., 2009).

Mineral elements can cause a therapeutic effect by themselves, or contribute to the daily intake, since some 25 elements have been identified as essential for keeping human health. Therefore, the essential and trace elements in food and medicinal plants have been studied by several research groups worldwide (i.e. Chizzola et al., 2008; Del Vitto et al., 2009; Kara, 2009; Martins et al., 2009; Nookabkaew et al., 2006). Moreover, 
determining the level of minerals can contribute both to an effective quality control and traceability of herbal medicines, and even to establish the safety of its use in terms of levels of toxic elements.

The objective of this study was to evaluate and describe the mineral contents ( $\mathrm{Al}, \mathrm{Ca}, \mathrm{Co}, \mathrm{Cr}, \mathrm{Cu}$, $\mathrm{Fe}, \mathrm{K}, \mathrm{Li}, \mathrm{Mg}, \mathrm{Mn}, \mathrm{Na}, \mathrm{P}, \mathrm{Se}$ and $\mathrm{Zn}$ ) in crude drugs and infusion obtained by ICP-OES from five medicinal herbs characterized by their mild sedative effects: Melissa officinalis L., Lamiaceae, Nepeta cataria L., Lamiaceae, Passiflora caerulea L., Passifloraceae, Tilia $x$ moltkei Späth ex C.K. Schneid., Tiliaceae, and Valeriana officinalis L., Caprifoliaceae. The results were compared to weighted values found in plants as well as previously settled limits for herbal medicines and derived products.

\section{Materials and Methods}

\section{Plant material}

Ten samples of each plant species were harvested in the field or acquired in regional markets, as suitable, in the summer 2006-2007. Plant specimens were authenticated by vouchers preserved at Herbarium, Universidad Nacional de San Luis (acronym: UNSL) and identified by the botanists co-authors of this study, as follows: Melissa officinalis L., Lamiaceae (Argentina, San Luis city herbal market, UNSL-H \#830); Nepeta cataria L., Lamiaceae (Argentina, San Luis province, Pringles dept., Río Grande, March 23, 2007, L.A. Del Vitto \& E.M. Petenatti \#9432, UNSL); Passiflora caerulea L., Passifloraceae (Argentina, San Luis province, La Capital dept., vicinity of Juana Koslay city, March 21, 2007, L.A. Del Vitto \& E.M. Petenatti \#9431, UNSL); Tilia $x$ moltkei Späth ex C.K. Schneid., Tiliaceae (Argentina, San Luis city herbal market, UNSL-H \#832); and Valeriana officinalis L., Caprifoliaceae (Argentina, San Luis city herbal market, UNSL-H \#831).

\section{Assays}

\section{Sample preparation and extraction}

Botanical drugs were dried in an oven at 75 ${ }^{\circ} \mathrm{C}$ during $24 \mathrm{~h}$ until constant weight. Afterwards the material was ground using a Wiley 3379 series grinder and passed through a sieve $(0.50 \mathrm{~mm}$ diameter $)$. The powder $(2.0 \mathrm{~g})$ was transferred to a porcelain crucible and $5 \mathrm{~mL}$ of indium solution $\left(500 \mathrm{mg} \mathrm{L}^{-1}\right)$ was added as internal standard to evaluate the degree of recovery. One gram of each of the samples was dry-ashed in a crucible in furnace at $550{ }^{\circ} \mathrm{C}$ for about $7 \mathrm{~h}$. The ash was dissolved in $10.0 \mathrm{~mL}$ of $\mathrm{HCl}$ in a conical flask. The solution was filtered into a $100 \mathrm{~mL}$ standard flask and made up to the mark with distilled water, to determine micro and macroelements.

Infusions were made according to the Argentinian Pharmacopoeia (FNA, 1978), i.e. to $5 \mathrm{~g}$ of raw drug were added $100 \mathrm{~mL}$ of deionized water at 90 ${ }^{\circ} \mathrm{C}$, and then allowed to stand for $20 \mathrm{~min}$. The obtained infusions were filtered and evaporated to dryness. The residue was ashed in a muffle furnace for a minimum of $4 \mathrm{~h}$ at $480{ }^{\circ} \mathrm{C}$ and handled as above for the dry material. All chemicals used were of analytical grade.

\section{Analytical procedure}

Fourteen elements were determined in each sample by direct nebulization using an ICP-OES instrument (Varian Vista Pro, Melbourne, Australia). Working conditions for ICP-OES instrument were: forward power $1.4 \mathrm{~kW}$, coolant gas flow rate $15 \mathrm{~L}$ $\mathrm{min}^{-1}$, auxiliary gas flow rate $1.5 \mathrm{~L} \mathrm{~min}^{-1}$; nebulizer gas flow rate $0.68 \mathrm{~L} \mathrm{~min}^{-1}$; the viewing height was $8 \mathrm{~mm}$ above the load coil. This instrument is equipped with a Czerny-Turner monochromator, holographic diffraction grid and a VistaChip charge coupled device (CCD) array detector. The analytical quality was checked through analysis of a plant reference material (V-10 hay powder; International Atomic Energy Agency, Vienna, Austria).

\section{Statistical analysis}

A standard statistical procedure was adopted to obtain the final values of the elemental concentrations: for each sample, four independent measurements were carried out. Statistical analysis was performed using R software version 2.8.1 (R Development Core Team, 2008).

\section{Results and Discussion}

Mineral contents of raw samples

The overall compositions of five different herbal sedative species were evaluated through the ICPOES technique. Elements such as $\mathrm{Al}, \mathrm{Ca}, \mathrm{Co}, \mathrm{Cr}, \mathrm{Cu}, \mathrm{Fe}$, $\mathrm{K}, \mathrm{Li}, \mathrm{Mg}, \mathrm{Mn}, \mathrm{Na}, \mathrm{P}, \mathrm{Se}$ and $\mathrm{Zn}$ were simultaneously determined in samples of raw drugs and infusions.

The composition in macrominerals of the five medicinal herbs under study is detailed in Table 1.

Similar mineral abundance profiles were observed among samples under study. Series of K, Ca and $\mathrm{Mg}$ appeared in decreasing order of concentration in all samples, except the concentration of $\mathrm{Ca}$ in Passiflora caerulea and Tilia $x$ moltkei, where this element was the richest relatively. The highest value 
of Ca was established in Passiflora caerulea (19.8 mg $\mathrm{g}^{-1}$ ), while Melissa officinalis was richest in $\mathrm{Mg}$ and $\mathrm{K}$ (4.03 and $16.90 \mathrm{mg} \mathrm{g}^{-1}$, respectively). M. officinalis and Valeriana officinalis showed the highest contents of $\mathrm{Fe}$ (0.90 and $0.97 \mathrm{mg} \mathrm{g}^{-1}$ respectively). $\mathrm{Al}, \mathrm{Na}$, and $\mathrm{P}$, were present at levels under $5 \mathrm{mg} \mathrm{g}^{-1}$.

The compositions in microminerals founded in crude drug are listed in Table 2.

To summarize, microminerals were present in the same sequence in all species, with significant quantities of $\mathrm{Mn}$ (104.3 to $\left.55 \mu \mathrm{g} \mathrm{g}^{-1}\right), \mathrm{Zn}$ (39.4 to 23.2 $\left.\mu \mathrm{g} \mathrm{g}^{-1}\right), \mathrm{Cu}$ (13.5 to $\left.4.8 \mu \mathrm{g} \mathrm{g}^{-1}\right), \mathrm{Li}\left(15.4\right.$ to $\left.4.4 \mu \mathrm{g} \mathrm{g}^{-1}\right)$, and minor contents (under $10 \mu \mathrm{g} \mathrm{g}^{-1}$ ) of $\mathrm{Cr}$ (4.9 to 1.8 $\left.\mu \mathrm{g} \mathrm{g}^{-1}\right)$, Co $\left(0.5\right.$ to $\left.0.2 \mu \mathrm{g} \mathrm{g}^{-1}\right)$, and Se $(0.5$ to $0.3 \mu \mathrm{g}$ $\left.\mathrm{g}^{-1}\right)$. Passiflora caerulea showed the highest values of Mn (followed by Valeriana officinalis with a close ratio), but the lower rates of $\mathrm{Cu}$. The highest contents of $\mathrm{Zn}, \mathrm{Cr}$, and $\mathrm{Co}$ were found in $V$. officinalis, while Melissa officinalis had the highest values of $\mathrm{Cu}$ and $\mathrm{Li}$; the last element reached more than twice the values of the other species. Finally, similar concentrations of Se were observed in the plants under study.

\section{Mineral contents of the infusions}

The concentration of macromineral elements determined in infusions is shown in Table 3.

Generally, there were large differences in the major nutrient input to the infusion by the five species; the differences ranging from close levels to more than 20 times higher. High contributions of $\mathrm{K}, \mathrm{Mg}$, and $\mathrm{Na}$ were observed on the infusions obtained from Melissa officinalis (852.3, 80.0, and $16.2 \mathrm{mg} \mathrm{L}^{-1}$, respectively), as expected according their highest concentrations on raw materials; but it is striking the highest transference of $\mathrm{Ca}$ in this species $\left(572.1 \mathrm{mg} \mathrm{L}^{-1}\right)$, because Passiflora caerulea had greater content of $\mathrm{Ca}$ in raw drug $(19.8 \mathrm{mg}$ $\mathrm{g}^{-1}$, Table 1). On the other hand, Valeriana officinalis release important levels of $\mathrm{Al}\left(1.9 \mathrm{mg} \mathrm{L}^{-1}\right), \mathrm{Fe}(2.5 \mathrm{mg}$ $\left.\mathrm{L}^{-1}\right)$, and $\mathrm{P}$ (111.4 $\left.\mathrm{mg} \mathrm{L}^{-1}\right)$ as we expect according to highest concentrations on raw materials.

Seven microminerals were determined on infusions (Table 4). No significant variations were found for Se, while $\mathrm{Zn}$ ranged from 5.3 to $0.4 \mathrm{mg} \mathrm{L}^{-1}$.

In infusions of Melissa officinalis, highest

Table 1. Concentrations of macroelements in raw material (dry weight basis, mean and \%RSD).

\begin{tabular}{|c|c|c|c|c|c|c|c|c|}
\hline Plant species & Parameters & $\mathrm{Al}$ & $\mathrm{Ca}$ & $\mathrm{Fe}$ & $\mathrm{K}$ & $\mathrm{Mg}$ & $\mathrm{Na}$ & $\mathrm{P}$ \\
\hline \multirow[t]{2}{*}{ Melissa officinalis } & Mean $\left[\mathrm{mg} \mathrm{g}^{-1}\right]$ & 0.92 & 14.8 & 0.90 & 16.90 & 4.05 & 0.49 & 2.76 \\
\hline & $\operatorname{RSD}[\%]$ & 10.5 & 7.4 & 6.5 & 1.7 & 4.3 & 1.5 & 2.2 \\
\hline \multirow[t]{2}{*}{ Nepeta cataria } & Mean $\left[\mathrm{mg} \mathrm{g}^{-1}\right]$ & 0.45 & 10.2 & 0.47 & 11.85 & 2.10 & 0.12 & 2.12 \\
\hline & $\operatorname{RSD}[\%]$ & 10.0 & 7.3 & 4.7 & 0.9 & 0.11 & 1.0 & 1.7 \\
\hline \multirow[t]{2}{*}{ Passiflora caerulea } & Mean $\left[\mathrm{mg} \mathrm{g}^{-1}\right]$ & 0.64 & 19.8 & 0.65 & 16.10 & 2.00 & 0.42 & 2.60 \\
\hline & $\operatorname{RSD}[\%]$ & 6.0 & 2.2 & 5.6 & 1.2 & 3.1 & 8.0 & 2.0 \\
\hline \multirow[t]{2}{*}{ Tilia x moltkei } & Mean $\left[\mathrm{mg} \mathrm{g}^{-1}\right]$ & 0.31 & 13.9 & 0.22 & 9.95 & 2.30 & 0.12 & 2.30 \\
\hline & $\mathrm{RSD}[\%]$ & 10.0 & 2.9 & 2.8 & 1.1 & 11.2 & 1.0 & 1.6 \\
\hline \multirow[t]{2}{*}{ Valeriana officinalis } & Mean $\left[\mathrm{mg} \mathrm{g}^{-1}\right]$ & 1.00 & 3.2 & 0.98 & 8.25 & 1.32 & 0.19 & 3.06 \\
\hline & $\operatorname{RSD}[\%]$ & 7.0 & 1.1 & 8.0 & 3.1 & 3.2 & 2.6 & 2.7 \\
\hline Ponderate values in plants ${ }^{\mathrm{a}}$ & {$\left[\mathrm{mg} \mathrm{g}^{-1}\right]$} & $0.5-2.0$ & $2.0-35.0$ & $0.025-0.3$ & $5.0-60.0$ & $1.0-8.0$ & trace & $1.0-8.0$ \\
\hline \multicolumn{9}{|l|}{ aDuke et al., 2002.} \\
\hline Plant species & Parameters & $\mathrm{Co}$ & $\mathrm{Cr}$ & $\mathrm{Cu}$ & $\mathrm{Li}$ & $\mathrm{Mn}$ & $\mathrm{Se}$ & $\mathrm{Zn}$ \\
\hline \multirow[t]{2}{*}{ Melissa officinalis } & Mean [mg g-1] & 0.45 & 1.96 & 13.50 & 15.40 & 63.50 & 0.49 & 30.00 \\
\hline & $\operatorname{RSD}[\%]$ & 0.9 & 5.4 & 11.8 & 2.5 & 5.17 & 2.7 & 3.5 \\
\hline \multirow[t]{2}{*}{ Nepeta cataria } & Mean $\left[\mathrm{mg} \mathrm{g}^{-1}\right]$ & 0.35 & 2.40 & 10.22 & 6.37 & 59.60 & 0.32 & 36.10 \\
\hline & $\operatorname{RSD}[\%]$ & 0.7 & 3.4 & 10.2 & 8.9 & 2.36 & 11.0 & 5.7 \\
\hline \multirow[t]{2}{*}{ Passiflora caerulea } & Mean [mg g-1] & 0.35 & 1.82 & 4.80 & 5.50 & 104.27 & 0.50 & 33.35 \\
\hline & $\operatorname{RSD}[\%]$ & 0.9 & 6.1 & 6.4 & 1.9 & 5.75 & 4.1 & 4.3 \\
\hline \multirow[t]{2}{*}{ Tilia $x$ moltkei } & Mean $\left[\mathrm{mg} \mathrm{g}^{-1}\right]$ & 0.25 & 2.05 & 10.23 & 4.52 & 54.90 & 0.48 & 23.20 \\
\hline & $\operatorname{RSD}[\%]$ & 1.7 & 8.3 & 8.0 & 8.1 & 4.95 & 6.0 & 4.3 \\
\hline \multirow[t]{2}{*}{ Valeriana officinalis } & Mean [mg g $\left.{ }^{-1}\right]$ & 0.50 & 4.87 & 5.80 & 4.40 & 91.30 & 0.31 & 39.40 \\
\hline & $\mathrm{RSD}[\%]$ & 0.4 & 9.9 & 3.1 & 10.2 & 10.41 & 6.1 & 6.8 \\
\hline Ponderate values in plants & {$\left[\mathrm{mg} \mathrm{g}^{-1}\right]$} & $0.02-1^{\mathrm{a}}$ & $0.1-0.5^{\mathrm{a}}$ & $4-30^{b}$ & $3-5^{a}$ & $15-800^{b}$ & $0.01-2^{a}$ & $15-800^{b}$ \\
\hline
\end{tabular}

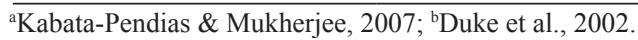


concentration of $\mathrm{Cu}\left(0.25 \mathrm{mg} \mathrm{L}^{-1}\right)$ and $\mathrm{Li}(0.30 \mathrm{mg}$ $\left.\mathrm{L}^{-1}\right)$ was transferred, in correlation with the high content in raw drug. Turn, Passiflora caerulea gave the highest levels of $\mathrm{Mn}\left(2.35 \mathrm{mg} \mathrm{L}^{-1}\right)$, while Tilia $x$ moltkei provided highest concentration of $\mathrm{Zn}(5.3 \mathrm{mg}$ $\left.\mathrm{L}^{-1}\right)$. To infusions of Passiflora caerulea and Valeriana officinalis was transferred the highest level of Co (0.06 $\left.\mathrm{mg} \mathrm{L}^{-1}\right)$.

As seen, the transport rate of different chemical species to infusion has varied greatly, not only among the minerals, but taking account different plant species. Average extraction rate varied from about $99 \%(\mathrm{~K})$ to $0.51 \%(\mathrm{Fe})$. The extractabilities for $\mathrm{P}, \mathrm{Na}, \mathrm{Mg}$ and $\mathrm{Ca}$ were ranged from $31 \%$ to $47 \%$, while $\mathrm{Zn}$, Co and $\mathrm{Se}$ varied from $10 \%$ to $16 \%$. Finally, extractabilities of $\mathrm{Cu}$, $\mathrm{Li}, \mathrm{Mn}, \mathrm{Cr}$, and $\mathrm{Al}$ were from $1.8 \%$ to $3 \%$. Summarizing, higher variations were observed in the macro and micromineral inputs to the infusion especially for Zinc, such as in Melissa officinalis (2.7\%) compared with Tilia $x$ moltkei $(46.0 \%)$.

\section{Contribution to the dietary intake}

A typical treatment with any of these drugs, as herbal infusion, consists in the daily intake of three to four teacups, which can vary from 150 to $250 \mathrm{~mL}$ each one. Thus arises the following table about the average daily intakes (ADI) of minerals, based on the concentration of elements transferred by the crude drug to the infusion, that were compared to the recommended daily allowance (RDA) settled by international health authorities (Table 5).

Among the infusions of the studied species, Melissa officinalis has supplied the highest percentages of RDA in $\mathrm{Ca}, \mathrm{K}, \mathrm{Mg}, \mathrm{Na}, \mathrm{Cu}$, and $\mathrm{Li}$; Valeriana officinalis has provided the highest levels of $\mathrm{Al}, \mathrm{Fe}$, $\mathrm{P}$, and $\mathrm{Cr}$ (the last in the same proportion as Nepeta cataria); Passiflora caerulea showed the highest contributions of $\mathrm{Mn}$ and Se, while Tilia $x$ moltkei provided the highest giving of $\mathrm{Zn}$ (note: the RDA for Co is not known).

It is remarkable that the minimum rates of contribution to RDA apply to Tilia $x$ moltkei, mainly for $\mathrm{Al}, \mathrm{Fe}, \mathrm{K}, \mathrm{Mg}, \mathrm{P}, \mathrm{Cr}, \mathrm{Mn}$, and $\mathrm{Se}$; this same condition was seen in Passiflora caerulea for $\mathrm{Cu}$ and $\mathrm{Li}$, in Melissa officinalis for $\mathrm{Zn}$, in Valeriana officinalis for $\mathrm{Ca}$, and finally, in Nepeta cataria for $\mathrm{Na}$.

Table 3. Concentrations of macroelements released to infusions (mean and \%RSD).

\begin{tabular}{|c|c|c|c|c|c|c|c|c|}
\hline Plant species & Parameters & $\mathrm{Al}$ & $\mathrm{Ca}$ & $\mathrm{Fe}$ & $\mathrm{K}$ & $\mathrm{Mg}$ & $\mathrm{Na}$ & $\mathrm{P}$ \\
\hline \multirow[t]{2}{*}{ Melissa officinalis } & Mean $\left[\mathrm{mg} \mathrm{g}^{-1}\right]$ & 0.31 & 572.14 & 0.23 & 852.32 & 80.05 & 16.23 & 70.15 \\
\hline & RSD [\%] & 0.01 & 86.44 & 0.05 & 37.76 & 10.20 & 1.78 & 6.83 \\
\hline \multirow[t]{2}{*}{ Nepeta cataria } & Mean $\left[\mathrm{mg} \mathrm{g}^{-1}\right]$ & 0.34 & 114.66 & 0.27 & 509.41 & 39.70 & 1.40 & 35.30 \\
\hline & RSD [\%] & 0.03 & 8.97 & 0.03 & 23.70 & 3.89 & 0.01 & 0.66 \\
\hline \multirow[t]{2}{*}{ Passiflora caerulea } & Mean $\left[\mathrm{mg} \mathrm{g}^{-1}\right]$ & 0.43 & 311.43 & 0.30 & 741.14 & 54.60 & 10.50 & 68.90 \\
\hline & RSD [\%] & 0.01 & 26.15 & 0.04 & 24.79 & 3.43 & 1.44 & 3.56 \\
\hline \multirow[t]{2}{*}{ Tilia x moltkei } & Mean $\left[\mathrm{mg} \mathrm{g}^{-1}\right]$ & 0.25 & 57.62 & 0.16 & 225.30 & 19.78 & 1.95 & 31.58 \\
\hline & RSD [\%] & 0.06 & 5.52 & 0.01 & 8.32 & 0.98 & 0.05 & 1.37 \\
\hline \multirow[t]{2}{*}{ Valeriana officinalis } & Mean $\left[\mathrm{mg} \mathrm{g}^{-1}\right]$ & 1.90 & 25.82 & 2.50 & 422.60 & 24.83 & 3.85 & 111.42 \\
\hline & RSD [\%] & 0.05 & 3.62 & 0.15 & 6.91 & 3.19 & 0.48 & 7.88 \\
\hline
\end{tabular}

Table 4. Concentrations of microminerals released to infusions (mean and \%RSD).

\begin{tabular}{|c|c|c|c|c|c|c|c|c|}
\hline Plant species & Parameters & $\mathrm{Mn}$ & $\mathrm{Co}$ & $\mathrm{Cr}$ & $\mathrm{Cu}$ & $\mathrm{Li}$ & $\mathrm{Se}$ & $\mathrm{Zn}$ \\
\hline \multirow[t]{2}{*}{ Melissa officinalis } & Mean $\left[\mathrm{mg} \mathrm{g}^{-1}\right]$ & 0.45 & 0.01 & 0.02 & 0.25 & 0.30 & 0.02 & 0.40 \\
\hline & $\mathrm{RSD}[\%]$ & 0.06 & 0.00 & 0.01 & 0.05 & 0.11 & 0.01 & 0.09 \\
\hline \multirow[t]{2}{*}{ Nepeta cataria } & Mean $\left[\mathrm{mg} \mathrm{g}^{-1}\right]$ & 0.60 & 0.01 & 0.03 & 0.17 & 0.05 & 0.02 & 1.62 \\
\hline & $\mathrm{RSD}[\%]$ & 0.03 & 0.00 & 0.02 & 0.04 & 0.01 & 0.01 & 0.32 \\
\hline \multirow[t]{2}{*}{ Passiflora caerulea } & Mean $\left[\mathrm{mg} \mathrm{g}^{-1}\right]$ & 2.35 & 0.06 & 0.03 & 0.06 & 0.03 & 0.02 & 3.40 \\
\hline & $\operatorname{RSD}[\%]$ & 0.18 & 0.09 & 0.02 & 0.01 & 0.05 & 0.01 & 0.93 \\
\hline \multirow[t]{2}{*}{ Tilia $x$ moltkei } & Mean $\left[\mathrm{mg} \mathrm{g}^{-1}\right]$ & 0.32 & 0.01 & 0.01 & 0.07 & 0.06 & 0.02 & 5.30 \\
\hline & RSD [\%] & 0.04 & 0.00 & 0.00 & 0.02 & 0.01 & 0.01 & 0.30 \\
\hline \multirow[t]{2}{*}{ Valeriana officinalis } & Mean $\left[\mathrm{mg} \mathrm{g}^{-1}\right]$ & 1.24 & 0.06 & 0.03 & 0.14 & 0.07 & 0.02 & 0.80 \\
\hline & RSD [\%] & 0.04 & 0.05 & 0.02 & 0.05 & 0.02 & 0.01 & 0.31 \\
\hline
\end{tabular}


Table 5. Contribution of mineral elements from herbal infusions to average daily intake of minerals and comparison with recommended values of allowance.

\begin{tabular}{|c|c|c|c|c|c|c|c|c|c|c|c|}
\hline \multirow{2}{*}{$\begin{array}{l}\overrightarrow{\overrightarrow{0}} \\
\stackrel{\overrightarrow{0}}{\vec{D}}\end{array}$} & \multicolumn{2}{|c|}{ Melissa officinalis } & \multicolumn{2}{|c|}{ Nepeta cataria } & \multicolumn{2}{|c|}{ Passiflora caerulea } & \multicolumn{2}{|c|}{ Tilia $\times$ moltkei } & \multicolumn{2}{|c|}{ Valeriana officinalis } & \multirow{2}{*}{$\begin{array}{c}\text { RDA } \\
\text { mg day }^{-1}\end{array}$} \\
\hline & $\begin{array}{c}\text { ADI } \\
{\left[\mathrm{mg} \mathrm{day}^{-1}\right]}\end{array}$ & CDI [\%] & $\begin{array}{c}\text { ADI } \\
{\left[\mathrm{mg} \mathrm{day}^{-1}\right]}\end{array}$ & CDI [\%] & $\begin{array}{c}\text { ADI } \\
{\left[\mathrm{mg} \mathrm{day}^{-1}\right]}\end{array}$ & CDI [\%] & $\begin{array}{c}\text { ADI } \\
{\left[\mathrm{mg} \mathrm{day}^{-1}\right]}\end{array}$ & CDI [\%] & $\begin{array}{c}\text { ADI } \\
{\left[\mathrm{mg} \mathrm{day}^{-1}\right]}\end{array}$ & CDI $[\%]$ & \\
\hline $\mathrm{Al}$ & 0.14 & 1.66 & 0.15 & 1.78 & 0.19 & 2.28 & 0.11 & 1.31 & 0.85 & 10.05 & $2-10$ \\
\hline $\mathrm{Ca}$ & 257.47 & 25.75 & 51.60 & 5.16 & 140.15 & 14.01 & 25.93 & 2.59 & 11.62 & 1.16 & $1,000-1,200$ \\
\hline $\mathrm{Fe}$ & 0.10 & 0.70 & 0.12 & 0.81 & 0.14 & 0.90 & 0.07 & 0.47 & 1.12 & 7.48 & $8-18$ \\
\hline K & 383.54 & 8.16 & 274.23 & 5.83 & 333.51 & 7.10 & 101.38 & 2.16 & 190.04 & 4.04 & 4,700 \\
\hline $\mathrm{Mg}$ & 36.02 & 11.26 & 17.87 & 5.58 & 24.57 & 7.68 & 8.90 & 2.78 & 11.17 & 3.49 & $310-320$ \\
\hline $\mathrm{Na}$ & 7.31 & 0.49 & 0.64 & 0.04 & 4.73 & 0.32 & 0.88 & 0.06 & 1.73 & 0.12 & 1,500 \\
\hline $\mathrm{P}$ & 31.56 & 3.16 & 15.88 & 1.59 & 31.01 & 3.10 & 14.21 & 1.40 & 50.11 & 5.01 & 700 \\
\hline Co & 0.005 & $\mathrm{nc}$ & 0.005 & $\mathrm{nc}$ & 0.026 & $\mathrm{nc}$ & 0.005 & $\mathrm{nc}$ & 0.025 & $\mathrm{nc}$ & unk \\
\hline $\mathrm{Cr}$ & 0.007 & 27.00 & 0.014 & 54.00 & 0.012 & 46.80 & 0.006 & 22.50 & 0.014 & 54.00 & 0.025 \\
\hline $\mathrm{Cu}$ & 0.113 & 1.13 & 0.077 & 0.77 & 0.029 & 0.29 & 0.031 & 0.31 & 0.065 & 0.65 & 0.9 \\
\hline $\mathrm{Li}$ & 0.137 & 27.30 & 0.024 & 4.73 & 0.014 & 2.80 & 0.025 & 4.95 & 0.030 & 6.00 & $0.2-0.6$ \\
\hline $\mathrm{Mn}$ & 0.203 & 10.14 & 0.269 & 13.46 & 1.058 & 52.90 & 0.143 & 7.13 & 0.556 & 27.79 & $1.8-2.3$ \\
\hline $\mathrm{Se}$ & 0.008 & 15.75 & 0.008 & 15.75 & 0.009 & 18.00 & 0.007 & 14.40 & 0.008 & 15.75 & 0.055 \\
\hline $\mathrm{Zn}$ & 0.180 & 1.80 & 0.726 & 7.26 & 1.590 & 15.90 & 2.400 & 24.00 & 0.359 & 3.59 & 8-11 \\
\hline
\end{tabular}

ADI: Average daily intake. CDI: Contribution to daily intake. RDA: Recommended Dietary Allowance; nd: non determined yet; nc: non calculated; unk: unknown.

\section{Discussion}

As a whole, the mineral profile obtained for the five medicinal herbs studied is comparable to the levels that usually found in different anatomical parts of plants (Duke et al., 2002). Samples of crude drug of Melissa officinalis, Nepeta cataria, Passiflora caerulea, Tilia $x$ moltkei and Valeriana officinalis were rich in essential macrominerals, especially $\mathrm{K}, \mathrm{Ca}, \mathrm{Mg}$, and $\mathrm{P}$ (mostly in that descending order), with low contents of $\mathrm{Fe}$ and $\mathrm{Na}$. Mineral content on Melissa officinalis and Tilia $x$ moltkei is agree with those obtained by other authors in similar studies (Başgel \& Erdemoğlu, 2006; Özcan et al., 2008; Raczuk et al., 2008). In addition, microminerals were present in relative large quantities in $\mathrm{Mn}, \mathrm{Zn}$, and $\mathrm{Cu}$, and to a lesser extent for $\mathrm{Li}$, and even lower values for $\mathrm{Cr}, \mathrm{Se}$, and $\mathrm{Co}$, always in that sequence in all studied species. These values varied widely depending on the different plant species.

According to the Dietary Recommended Intakes (DRI) for minerals settled by reference health authorities (Food \& Nutrition Board, 2009), their content in the infusions set in this study were much lower than the limits. Although none of the infusions is in itself a complete source of minerals, highlight the contribution of $\mathrm{Ca}, \mathrm{Mg}, \mathrm{K}, \mathrm{Li}$ (from Melissa officinalis tea), Zn (from Tilia $x$ moltkei) and Se (from Passiflora caerulea), in contrast with the other studied herbs. Taking in mind that $\mathrm{Ca}, \mathrm{Mg}, \mathrm{K}, \mathrm{Zn}$ and $\mathrm{Se}$ are actively involved in the synthesis of neurotransmitters and receptors as well as in the transmission of nerve impulses (Black, 2003; Tepper, 2006), and lithium salts are useful in the treatment of some nervous illness, the intake of infusions of the studied herbs (containing these minerals in an interesting level) may contribute in an indirect way to the therapeutic effects (mainly psycholeptic, Carlini, 2003) of these drugs.

Besides the case of possible punctual contamination with toxic elements, especial attention should be considered, when these herbs are used in phytomedicine. Despite of low levels of some minerals in these products, even trace amounts of metals may control, trigger or stop the biochemical reactions in the living organisms and modulate pharmacological activity of these herbs. This study could be contribute to the future investigations on the interactions between macro and microminerals in these herbs and the rest of its biologically active components. Therefore, it is necessary to reach a wide knowledge about mineral content in these herbs, contributing to design a best quality control of plant materials.

\section{References}

Başgel S, Erdemoğlu SB 2006. Determination of mineral and trace elements in some medicinal herbs and their infusions consumed in Turkey. Sci Total Environ 359: $82-89$.

Black M 2003. Micronutrient deficiencies and cognitive functioning. J Nutr 133 Suppl: 3927-3931.

Carlini EA 2003. Plants and the central nervous system. 
Pharmacol Biochem Behav 75: 501-512.

Carrasco MC, Vallejo JR, Pardo-de-Santayana M, Peral D, Martín MA, Altimiras J 2009. Interactions of Valeriana officinalis L. and Passiflora incarnata L. in a patient treated with lorazepam. Phytother Res 12: 1795-1796.

Cass H 2004. Herbs for the nervous system: Ginkgo, kava, valerian, passionflower. Seminars in Integrative Medicine 2: 82-88.

Chizzola R, Michitsch H, Mitteregger US 2008. Extractability of selected mineral and trace elements in infusions of chamomile. Int J Food Sci Nutr 59: 451-456.

Coleta M, Campos MG, Cotrim MD, da Cunha P 2001. Comparative evaluation of Melissa officinalis L., Tilia europaea L., Passiflora edulis Sims. and Hypericum perforatum $\mathrm{L}$. in the elevated plus maze anxiety test. Pharmacopsychiatry 34 (suppl. 1): S20-1.

Del Vitto LA, Petenatti EM, Petenatti ME, Mazza SM, Marchevsky EJ 2009. Major and trace elements contents in crude drug and infusions of two south american species of Achyrocline (Asteraceae) called "Marcelas". Lat Am J Pharm 28: 552-559.

Duke JA, Bogenschutz-Godwin MJ, du Cellier J, Duke PA 2002. Handbook of medicinal herbs. 2 ed. Boca Raton: CRC Press.

Ernst E 2002. Toxic heavy metals and undeclared drugs in Asian herbal medicines. Trends Pharmacol Sci 23: 136-139.

FNA (Farmacopea Nacional Argentina) 1978. Codex medicamentarius argentino. 6 ed. Buenos Aires: Codex, p. 581

Food \& Nutrition Board (U.S.A.). Dietary Reference Intakes. http://www.nap.edu, access in November 2009.

Kabata-Pendias A, Mukherjee A 2007. Trace elements from soils to human. Berlin/Heidelberg: Springer, p. 57.

Kara D 2009. Evaluation of trace metal concentrations in some herbs and herbal teas by principal component analysis. Food Chem 114: 347-354.

Kinrys G, Coleman E, Rothstein E 2009. Natural remedies for anxiety disorders: potential use and clinical applications. Depress Anxiety 26: 259-265.

Martins AS, Alves CN, Lameira OA, Santos AS, Sarkis Müller RC 2009. Avaliação de minerais em plantas medicinais amazônicas. Rev Bras Farmacogn 19: 621-625.
Murphy PA, Kern SE, Stanczyk FZ, Westhoff CL 2005. Interaction of St. John's Wort with oral contraceptives: effects on the pharmacokinetics of norethindrone and ethinyl estradiol, ovarian activity and breakthrough bleeding. Contraception 71: 402-408.

Nookabkaew S, Rangkadilok N, Satayavivad J 2006. Determination of trace elements in herbal tea products and their infusions consumed in Thailand. J Agric Food Chem 54: 6939-6944.

Özcan MM, Ünver A, Uçar T, Arslan D 2008. Mineral content of some herbs and herbal teas by infusion and decoction. Food Chem 106: 1120-1127.

Pollak L, Morad Y, Dabby R, Watemberg N, Bar-Dayan Y 2009. Prevalence of central nervous system diseases. Neuropediatrics 40: 275-279.

R Development Core Team 2008. R: a language and environment for statistical computing. Vienna, Austria: R Foundation for Statistical Computing.

Raczuk J, Biardzka E, Daruk J 2008. The content of Ca, $\mathrm{Mg}, \mathrm{Fe}$ and $\mathrm{Cu}$ in selected species of herbs and herb infusions. Roczn Panstw Zakl Hig 59: 33-40.

Roth T, Drake C 2004. Evolution of insomnia: current status and future direction. Sleep Med 5 Suppl: 23-30.

Tepper BJ 2006. Minerals, the central nervous system and behavior. In J Worobey, BJ Tepper, RB Kanarek (eds.) Nutrition and behavior: a multidisciplinary approach. Cambridge: CABI Publ., p. 98-117.

World Health Organization 2004. WHO guidelines on safety monitoring of herbal medicines in pharmacovigilance systems. Geneva: WHO, p. 82.

World Health Organization 2007. WHO monographs on selected medicinal plants. vol. 3. Geneva: WHO, p. 376.

Yeh GY, Eisenberg DM, Davis RB, Phillips RS 2002. Use of complementary and alternative medicine among persons with diabetes mellitus: results of a national survey. Am J Public Health 92: 1648-1652.

\section{*Correspondence}

Roberto G. Pellerano

INQUISAL - CONICET

Ej. de los Andes 950, D5700HHW San Luis, Argentina gpellera@conicet.gov.ar

Tel.: +542652426744

Fax: +54 2652430224 